\title{
Anna Pytasz-Kołodziejczyk, Zasoby wodne w dobrach wielkoksiażę- cych zachodniej Grodzieńszczyzny w XVI w. Administracja i eksploata- cja, Olsztyn 2017, 292 ss., il., mapy, fot.
}

W 2017 roku na rynku publikacji akademickich ukazała się praca Anny Pytasz-Kołodziejczyk Zasoby wodne w dobrach wielkoksiążcych zachodniej Grodzieńszczyzny w XVI w. Administracja i eksploatacja ${ }^{1}$. Próba podjęcia tego tematu wydaje się nie tylko interesująca, lecz także aktualna z różnych względów, chociażby dlatego, że niektóre działy geografii historycznej nie cieszą się zainteresowaniem badaczy ${ }^{2}$. Monografia pióra Anny Pytasz-Kołodziejczyk jest godna uwagi, gdyż porusza trudne oraz w pewnym stopniu zaniedbane zagadnienie dotyczące problematyki środowiska geograficznego oraz krajobrazu kulturalnego na pograniczu polsko-litewskokrzyżackim w epoce jagiellońskiej. Należy podkreślić, iż tematyka pracy mieści się w nurcie badań geograficzno-historycznych prowadzonych od dłuższego czasu przez ośrodek olsztyński ${ }^{3}$, w tym przez autorkę monografii, o czym świadczy jej dorobek wydawniczy ${ }^{4}$.

A. Pytasz-Kołodziejczyk, Zasoby wodne w dobrach wielkoksiążecych zachodniej Grodzieńszczyzny w XVI w. Administracja i eksploatacja, Olsztyn 2017, 292 ss.

2 G. Błaszczyk, Geografia historyczna Wielkiego Księstwa Litewskiego. Stan i perspektywy badań, wyd. 2 poprawione i uzupełnione, Poznań 2007, s. 15.

3 Szkice z dziejów społeczno-gospodarczych Podlasia i Grodzieńszczyzny od XV do XVI wieku, red. J. Śliwiński, Olsztyn 2005; Puszcze wielkoksiążęce na pótnocnym Podlasiu i zachodniej Grodzieńszczyźnie w XV-XVI wieku (podziały, administracja, stużby leśne i wodne), red. J. Śliwiński, Olsztyn 2007; J. Śliwiński, Grodzieńszczyzna i Podlasie $w$ XV-XVI wieku w Wielkim Księstwie Litewskim (wielkoksiążęce puszcze i włości, eksploatacja, pożary), Olsztyn 2010.

4 Wśród najważniejszych prac autorki w tym zakresie należy wymienić: A. Kołodziejczyk, Eksploatacja wód na Podlasiu i Grodzieńszczyźnie w XVI w. [w:] Szkice z dziejów spoteczno-gospodarczych Podlasia i Grodzieńszczyzny od XV do XVI wieku, red. J. Śliwiński, Olsztyn 2005, s. 33-60; eadem, Regulacje prawne dotyczqce wykorzystania zasobów wodnych w dobrach wielkoksiażęcych Wielkiego Księstwa Litewskiego za Jagiellonów, „Echa Przeszłości” 2010, t. XI, s. 43-51; eadem, Przemiany społeczno-gospodarcze na Podlasiu w XV-XVI wieku, Olsztyn 2012, 196 ss.; eadem, Z dziejów organizacji niewodnictw Grodzieńszczyzny w XVI w. [w:] Od antyku do współczesności, red. A. Kołodzi ejczyk, K. Łożyński, Olsztyn 2012, s. 111-126; eadem, Z badań nad zasobami wodnymi Wielkiego Księstwa Litewskiego. Niewodnictwa w świetle „Lietuvos Metrika” (do końca XVI w.) [w:] Litwa i jej sasiedzi w relacjach wzajemnych (XIII-XVI w.), red. A. Kołodziejczyk, R. Kubicki, M. Radoch, Olsztyn 2014, s. 227-237; A. Pytasz-Kołodziejczyk, Podróże ostatnich Jagiellonów na Litwę a kształtowanie się sieci komunikacyjnej i osadniczej Podlasia w pierwszej potowie XVI w. [w:] Via viatores quaerit. Mobilność społeczna w dziejach krajów Grupy Wyszehradzkiej, red. A. Teterycz-Puzio, L. Kościelak, E. Łączyńska, Słupsk 2016, s. 65-75; eadem, Wykorzystanie i ochrona zasobów wodnych w dobrach 
Za podstawowy problem badawczy autorka uznała przedstawienie całokształtu warunków wykorzystania zasobów wodnych w dobrach hospodarskich w zachodniej części powiatu grodzieńskiego w XVI wieku, uzasadniając celowość podjęcia tematu niezbyt imponującym stanem badań (s. 8) oraz innymi czynnikami.

Układ książki został logicznie przemyślany. Trzon recenzowanej monografii stanowią cztery rozdziały wzbogacone o tabele, zdjęcia oraz mapy.

Pracę otwiera rozdział Uwarunkowania historyczno-geograficzne ksztaltujace terytorium zachodniej Grodzieńszczyzny, w którym autorka skupiła się na omówieniu krajobrazu naturalnego regionu. Po wstępnym zarysie, traktującym o średniowiecznej historii powiatu grodzieńskiego, dokonała analizy procesów społeczno-politycznych, które ukształtowały podziały administracyjne w XV i XVI wieku (s. 27-31).

Podkreślę, iż ze względu na ograniczony zasób źródłowy do dziejów regionu Anna Pytasz-Kołodziejczyk nie miała łatwego zadania. Mimo to udało jej się odtworzyć fluktuacje klimatyczne w okresie średniowiecza, sieć hydrologiczną, stan surowców mineralnych (rudy żelaza i soli), stopień zalesienia oraz charakter drzewostanu, faunę, w tym najbardziej rozpowszechnione gatunki ryb w XIII-XVI wieku. Wart uwagi jest sporządzony spis 54 rzek oraz 53 jezior z obszaru Molawickiej, Odelskiej i Kryńskiej puszy (s. 38-56, 67).

Autorka nie ogranicza się do rekonstrukcji stosunków wodnych w późnym średniowieczu oraz wczesnej dobie nowożytnej, lecz śledzi zmiany krajobrazu naturalnego zachodzące pod wpływem czynnika antropogenicznego w późniejszym czasie.

W drugim rozdziale, zatytułowanym Podstawy prawno-własnościowe organizacji $i$ wykorzystania zasobów wodnych $w$ dobrach wielkoksiążęcych na zachodniej Grodzieńszczyźnie XVI wieku, scharakteryzowała zagadnienie formowania się struktury własnościowej zasobów wodnych oraz jej regulacji prawnych.

Zdaniem autorki o usprawnieniu systemu eksploatacji oraz nadzoru nad zasobami wodnymi w Wielkim Księstwie Litewskim można mówić dopiero od pierwszej połowy XVI wieku. Wzrost aktywności gospodarczej wielkiego księcia wynikał z konieczności zasilania niezbyt zasobnego skarbu (s. 72-73), pociągającej za sobą nowe rozwiązania prawne (statuty litewskie lub liczne ustawy, w tym pierwsze zarządzenie królowej Bony z 1524 r.), regulacje stosunków własnościowych, a także rozwój aparatu zarządzania w dobrach wielkoksiążęcych.

Anna Pytasz-Kołodziejczyk wnikliwie analizuje - oczywiście w takim stopniu, w jakim pozwoliły jej na to źródła - swoisty przewrót charakteryzujący się kruszeniem starych stosunków prawno-własnościowych (tzw. stariny, czyli zwyczajowego prawa korzystania z wód) obowiązujących w XV wieku na rzecz nowych zasad eksploatacji i zarządzania stosunkami wodnymi oraz bardziej racjonalnych obciążeń ludności włościańskiej.

W dalszej części pracy autorka omawia zagadnienie zarządzania dobrami hospodarskimi w XV i pierwszej połowie XVI stulecia, analizując funkcje poszczególnych urzędników (np. sprawcy dworu grodzieńskiego, rewizora, leśniczego) oraz

wielkoksiażęcych Wielkiego Księstwa Litewskiego w XVI w. (na przykładzie Podlasia i zachodniej Grodzieńszczyzny), „Historyka. Studia Metodologiczne” 2016, nr 46, s. 45-62. 
wyodrębnienie się służby rybackiej w każdej z włości na czele z niewodniczym. Książkę zamyka próba ukazania znaczenia gospodarczego rzek, jezior i stawów oraz procesu eksploatacji dóbr wodnych w dobrach hospodarskich.

Nie omawiając dogłębnie treści pracy, należy zauważyć, że analizowana monografia stanowi kompleksowe opracowanie jednego z aspektów działalności gospodarczej i jej warunków na wybranym terenie w XV i XVI wieku.

Pewne kontrowersje wzbudza problem ram terytorialnych ujętych w tytule książki. Badany obszar określany jako Zachodnia Grodzieńszczyzna to teren położony na zachód od Niemna do granicy z Prusami i Polską. Należy zauważyć, że jest to termin ahistoryczny, raczej niespotykany w przekazach źródłowych. Na pewno bez problemu można było wykorzystać termin „Zachodnia cześć powiatu grodzieńskiego”.

Próbując uzasadnić wybór tematu, autorka podkreśla, że badany region charakteryzował się gęstą siecią rzek i jezior oraz „znaczącym zalesieniem”, co wywarło wpływ na formy gospodarcze oraz procesy osadnicze (s. 32-33). Z tymi wnioskami można się zgodzić. Kontynuując swoje rozważania, zauważa, iż „warunki te swym charakterem odbiegały od pozostałych części WKL w XV i XVI w.” (s. 9, 225). Zwracam uwagę na te wnioski, ponieważ autorka pracy w żaden sposób nie uzasadnia tej tezy kolidującej z ustaleniami geografów.

Wypada zapytać: czy zalesienie i akweny na pozostałym obszarze WKL nie występowały? Warto nadmienić, że po wschodniej stronie Niemna w powiecie grodzieńskim leżały puszcza jezierska i biersztańska, gdzie jeziora nie były rzadkością. W związku z tym nasuwa się pytanie, czy warunki przyrodnicze zachodniej części powiatu grodzieńskiego istotnie różniły się od środowiska naturalnego innych regionów Wielkiego Księstwa Litewskiego i tym samym nie były warte uwagi?

Geografowie wyróżniają Pojezierze Wschodniobałtyckie, czyli region fizycznogeograficzny składający się z kilku makroregionów (o tym autorka pisze na s. 34). Pas jezior polodowcowych ciągnie się od Mazur przez Pojezierze Suwalskie i Sejneńskie oraz teren województwa trockiego i wileńskiego aż po połockie (Pojezierze Litewskie i Pojezierze Brasławskie). Niezupełnie jasne są więc kryteria, według których warunki przyrodnicze badanego terenu zostały uznane za specyficzne.

Praca historyka, szczególnie na etapie gromadzenia źródeł, obejmuje liczne kwerendy. Wypada się zgodzić, że niedostatek lub w ogóle brak źródeł pisanych powodują trudności w odtworzeniu krajobrazu naturalnego oraz jego przekształceń w okresie średniowiecza oraz w XVI wieku. Jak więc zauważono, po 1422 roku, znamionującym koniec wojny z Krzyżakami, w powiecie grodzieńskim rozwinęła się intensywna akcja osadnicza. W związku z tym można uznać za logiczny sposób postępowania autorki, która dokonuje rekonstrukcji środowiska geograficznego za pomocą źródeł pisanych oraz kartograficznych, a także archeologicznych oraz paleobotanicznych.

Uważne zapoznanie się z treścią książki świadczy o tym, że Anna Pytasz-Kołodziejczyk wykazała się dobrą znajomością literatury przedmiotu. Niemniej jednak chciałbym poczynić kilka uwag na temat bazy źródłowej, metodologii oraz technik badawczych stosowanych w pracy. Uzasadniając wybór ram chronologicznych rozprawy, autorka podkreśla, że „omówienie podjętych w opracowaniu zagadnień doprowadzono zasadniczo do końca XVI w.” (s. 9), które oparła „W głównej mierze 
na obszernej spuściźnie źródłowej” (s. 13). Można się zgodzić z faktem, że liczba materiałów rękopiśmiennych dotyczących badanego terenu nie jest imponująca: piętnastowieczne (nie mówiąc o czternastowiecznych) zasoby źródłowe są nikłe. W pracy wykorzystano więc $\mathrm{w}$ większości szesnastowieczne materiały, a przede wszystkim inwentarze, ordynacje pochodzące ze zbiorów krajowych (AGAD) oraz źródła drukowane (Metrykę Litewską, Statuty WKL, materiały ogłoszone drukiem przez Wileńską Komisję Archeograficzną oraz inne wydawnictwa).

Na potrzeby pracy Anna Pytasz-Kołodziejczyk przeprowadziła liczne kwerendy, przede wszystkim w krajowych archiwach oraz bibliotekach (Warszawa, Kraków, Wrocław, Białystok), jednak - jak zauważa - „bez większych rezultatów” (s. 19). Nie twierdzę, że był to całkiem mylny trop, aczkolwiek docieranie do materiałów źródłowych dotyczących jednego z powiatów Wielkiego Księstwa Litewskiego należałoby zestawić z procesem powstania tych lub innych urzędów, na przykład sądów ziemskich oraz wytworów ich kancelarii, a także wyjaśnić miejsca aktualnego przechowywania tychże zbiorów.

Takie materiały dotyczące tematu kryją archiwa litewskie i białoruskie. Nie znaczy to, że autorka je odrzuca, lecz raczej zbyt pobieżnie wykorzystuje, co nasuwa pewne uwagi. Przede wszystkim nie sposób nie odnieść się do stwierdzenia: ,z kolei w archiwach białoruskich zgromadzona jest pełniejsza dokumentacja w odniesieniu do Grodzieńszczyzny dopiero od XVII w. [sic?!]. Dotyczy to zarówno Centralnego Państwowego Archiwum Historycznego Białorusi w Mińsku, jak i Państwowego Archiwum Historycznego Białorusi w Grodnie, a także Litewskiego Państwowego Archiwum Historycznego w Wilnie. Jednak nie wniosła ona do problematyki omawianej w rozprawie znaczących uzupełnień" (s. 19-20, 229).

Oficjalna nazwa placówek białoruskich to Narodowe Archiwum Historyczne Białorusi oraz Narodowe Archiwum Historyczne Białorusi w Grodnie. Dokumentacja z archiwum w Mińsku nie mogła nie wnieść uzupełnień, skoro w placówce tej zachowało się 16 szesnastowiecznych ksiąg ziemskich grodzieńskich z lat 1556-1599 (zespół nr 1755), które są udostępniane badaczom. By nie być gołosłownym, podam przykład księgi ziemskiej grodzieńskiej z lat 1594-1595 (nr 13) zawierającej wzmianki o jeziorach Somowo, Dmitrowo, Orzechowo i Łopuchowo, o których autorka wspomina w monografii, koncentrując uwagę na rozwoju organizacyjnym niewodnictwa w drugiej połowie XVI wieku (s. 226).

Nie mniej wartościowe źródła przechowuje Litewskie Państwowe Archiwum Historyczne, między innymi materiały dotyczące powiatu trockiego graniczącego $\mathrm{z}$ powiatem grodzieńskim, $\mathrm{w}$ tym siedemnastowiecze księgi ziemskie i grodzkie tego powiatu (zespół 344, 345). Jak można sądzić, wykorzystanie tych zbiorów przy zastosowaniu metody retrogresywnej (czyli powiązanie faktów późniejszych z wcześniejszymi) pozwoliłyby na pogłębienie badanej problematyki.

Nie wszystkie sygnatury archiwalne zamieszczone w monografii zostały prawidłowo zapisane, na przykład zespół 10 ze zbiorów Litewskiego Państwowego Archiwum Historycznego to nie Zarząd Dóbr Królewskich, lecz zespół Trybunału Skarbowego WKL. Zespół Zarządu Dóbr Królewskich ma numer 110. 
Podobne błędy pojawiają się w przypisie 50 (s. 20), w którym autorka zauważa, że w archiwum w Grodnie jest przechowywany: „Fond 1882 (inwentarz miejski z 1651 r.), Fond 1143 (ordynacja puszcz z 1631 r.) czy Fond 1643 (Rewizja ekonomii grodzieńskiej z 1651 r.) [?!]”. Warto wspomnieć, że w chwili obecnej zespół numer 1882 wspomnianego archiwum jest zespołem prawosławnego dekanatu szereszewskiego powiatu prużańskiego XIX-XX wieku, zespół numer 1143 to kolekcja inwentarzy, zaś zespół numer 1643 to szczuczyński sąd gminny powiatu lidzkiego (lata 1914-1915).

Nasuwa się pytanie, skąd te informacje? Z treści przypisu wynika, że zostały one zaczerpnięte z pracy W. Pociechy Królowa Bona (t. 3) oraz artykułu M. Kuleckiego Kronika. Pobyt stużbowy w Mińsku (1994).

Uważam zatem, że mankamentem monografii jest brak uważnego odniesienia się nie tylko do białoruskich, ale i do litewskich zasobów archiwalnych (np. zasobów rękopiśmiennych Biblioteki Uniwersytetu w Wilnie oraz Biblioteki Litewskiej Akademii Nauk im. Wróblewskich). Pozostaje wyrazić nadzieję, iż przy okazji kolejnego wydania książki zostaną uwzględnione zasoby litewskich i białoruskich archiwów, co przyniosłoby dobre wyniki oraz pozwoliłoby zgłębić badaną problematykę.

Powołując się na prekursora badań nad geografią historyczną powiatu grodzieńskiego Jana Jakubowskiego, Anna Pytasz-Kołodziejczyk podkreśla, że „dla żadnego z terytoriów litewskich nie ma tak wielu źródeł geograficzno-historycznych, jak właśnie do Grodzieńszczyzny"5. Tu niestety popada w pułapkę aprioryczności, nie wykazując się krytycyzmem wobec zakładanej w literaturze tezy. Metoda naukowa, w tym wnioskowanie, wymaga unikania zbyt jednoznacznych twierdzeń, podania ich w wątpliwość oraz empirycznej weryfikacji, nawet jeśli były one wypowiedziane przez Mistrza, który - jak można sądzić - nie miał pełnego rozeznania w zbiorach archiwalnych ziem dawnego Wielkiego Księstwa Litewskiego.

$\mathrm{W}$ razie ewentualnego dopracowywania monografii należałoby uniknąć innych drobnych potknięć. Na przykład dwór królewski Horodnica (s. 36) nie zmienił nazwy i nie nazywa się Hornica. Obecnie jest to historyczna dzielnica Grodna, Hornica zaś jest wsią podmiejską ${ }^{6}$.

Warto też skorygować drobne błędy, np.:

s. 164-166, 172, 176 - pisownia nazwiska, jest: Mosalski, ma być: Massalski;

s. 229 - literówka, jest: eknomii, ma być: ekonomii;

s. 154 - wypadałoby uzupełnić wykaz leśniczych: w rachunkach dworu Zygmunta Augusta, opublikowanych w 1915 r., wzmiankuje się leśniczego grodzieńskiego Franciszka Czecholewskiego oraz leśniczego przełomskiego Alberta Radzemskiego ${ }^{7}$;

s. 83 , przypis 240 - podczas transliteracji białoruskich wyrazów zakradły się błędy: na przykład Сялянскае землеўладанне należy transliterować nie tak: Sâlâhskae zemleŭladahhe, lecz tak: Sâlânskae zemleŭladanne.

5 J. Jakubowski, Powiat Grodzieński w XVI wieku [w:] Prace Komisji Atlasu historycznego Polski, z. 3, Kraków 1935, s. 99.

6 Я. Рапан овіч, Слоўнік назваў населеных пунктаў Гродзенскай вобласці, Мінск 1982, s. 72.

7 Materiały do historii stosunków kulturalnych w XVI wieku: materiały z aktów skarbowych Archiwum głównego warszawskiego, Kraków 1915, s. 85. 
W wykorzystanej literaturze powinny się także pojawić artykuły Hienadzia Cychuna lub Aleha Lickiewicza ${ }^{8}$. Oczywiście wymienione uchybienia nie należą do poważnych mankamentów pracy.

Sumując powyższe uwagi, można stwierdzić, iż wobec braku kompleksowych opracowań na temat geografii historycznej powiatu grodzieńskiego rozprawa Anny Pytasz-Kołodziejczyk wypełnia poważną lukę. Tym samym wnosi znaczny wkład do polskiego dorobku naukowego $\mathrm{w}$ badaniach nad geografią historyczną Wielkiego Księstwa Litewskiego, a także skłania badaczy do podjęcia dalszych badań geograficzno-historycznych.

(1) http://orcid.org/0000-0003-3203-2894

\section{Jerzy Gordziejew}

Uniwersytet Jagielloński w Krakowie

Adres do korespondencji: hardziejeu@gmail.com

8 Г. Цыхун, Назіранні над гідраніміяй беластоцка-гродзенскага пагранічча [w:] Nazewnictwo na pograniczach etniczno-językowych: materiały z Międzynarodowej Konferencji Onomastycznej, Białystok-Supraśl, 26-27 X 1999, red. Z. Abramowicz, L. Dacewicz, Białystok 1999, s. 81-87; А. Ліцкевіч, Гародня і Гарадзенскі рэгіён у другой палове XIII-XIV ст.: назва і межы [w:] Гарадзенскі палімпсест 2012. Людзі даўняй Гародні XV-XX ст., Гродна 2013, s. 10-59. 